\title{
Turbulent Premixed Combustion in SI Engine
}

\author{
Mohammed Alhumairi ${ }^{1}$, Sami A. Nawi ${ }^{2}$ \\ ${ }^{1}$ Department of Mechanical Engineering, College of Engineering, Ozyegin University, Istanbul, \\ Turkey. \\ ${ }^{2}$ Department of Mechanical Engineering, College of Engineering, University of Diyala, Diyala, \\ Iraq.
}

Mohammed.alhumairi@ ozu.edu.tr, samialazawi64@yahoo.com

\begin{abstract}
The turbulent lean premixed combustion simulation is implemented in 4- stroke spark ignition (SI) engine. The Turbulent Flame speed Closure model (TFC) is used in different turbulent flow conditions. The model is tested for a variety of flame configurations such as turbulent flame speed, the heat release from the combustion and turbulent kinetic energy in the radial direction of the cylinder at $15.5 \mathrm{~mm}$ below the top dead center TDC point. The simulation performs in the three cases of the (intake / exhaust) valve timing. The exhaust valve case is an essential leverage on the turbulent flame specification. The combustion period is very important factor in SI engine which is controlled especially by the turbulent flame speed. The turbulent flame speed and heat transfer is ascendant less than $10 \%$ and $3 \%$ in case of intake and exhaust valves are closed respectively. Moreover, the results show that the brake power enhances less than $4 \%$ and more than $40 \%$ with increase fuel temperature $60 \mathrm{~K}$ and engine speed $3000 \mathrm{rpm}$ respectively.
\end{abstract}

Keywords: Turbulent premixed combustion, TFC model, SI engine, Valve timing.

Paper History: (Received: 19/4/2017; Accepted: 16/8/2017)

1. Introduction

The main goal of the combustion researches currently is to reduce emissions and to ameliorate the fuel economy [1, $2 \& 3]$. Lean combustion is a promising ersatz to traditional combustion [4]. However, it demonstrate high challenges, especially for spark ignition engines (SI) [5, 6 \&7]. Therefore, model utilized to predict such combustion has to be accurate, reliable and sever [1, 8, 9,10 \&11]. When burning the fuel with an oxidizer the main of energy conversion for this transportation is domestic heating and power generation [8, 12, $13 \& 14]$. In addition, most combustion processes are used fossil fuels, which participate to more $80 \%$ proportion of the universal energy consumption in 2010 (IEA, 2011). Then Fossil fuels are especially catchy for the transportation section, with more
$90 \%$ of all fuels used for transport in 2010 existence on fossil fuels. Furthermore, it's predicted for more $80 \%$ proportion in 2035 (IEA, 2011). In addition, most of an engine in vehicles today is used in internal combustion (IC) engines, which burn fossil fuels to convert chemical energy into mechanical energy. The problems accompanied with the combustion of the fuels are pollutants e.g. (soot, unburned hydrocarbons, carbon monoxide, oxides of nitrogen and sulfur oxides). Moreover, combustion caused the most concentrations of $(\mathrm{CO} 2)$ in the atmosphere. These issues have grown from the fact that fossil fuel resources are limited. Therefore, they are an essential to reduce emissions and increase combustion efficiencies [1].

In premixed combustion the fuel and air are mixed homogeneously before entering the intake section $[15,16,17,18,19,20 \& 21]$. The simplest pattern of this combustion is the spark-ignition (SI) engines and the gas turbines for power generation. The ultimate challenge connected with turbulent combustion is to understand the interaction between combustion and turbulence over a broad range of length and time scales [22 \&23]. One of the important magnitudes for turbulent premixed combustion is the turbulent flame speed [24, $25,26,27 \& 28]$, which is indicated for the mixture will be burnt.

L. Liang and R. Reitz [2] used KIVA-3V modeling for (SI) engine simulation to predict the fuel oxidation and pollutants formation. They found the prediction of the cylinder pressure and engine out gases and compared with the experiments gives good agreement.

C. Hall, et al [3] used the generalize combustion phasing model for fuel flexible in SI engines. They found the efficiencies of combustion are perfect tied maximum CA50 (crank angle when $50 \%$ of fuel is burned) for an engines.

The main objective of the present work is to study the demeanor and foretell trend of the turbulent flame speed, turbulent kinetic energy, the heat released and fuel temperature from the combustion in the cylinder spark ignition 
engines at different valve timing in order to reduce exhaust emissions and increase engine performance.

\section{2-Engine Specification and Computational Analysis}

The two main valves, timing in SI engines, intake \& exhaust valves are depicted in Figure 1. This study is performed in the line below TDC point at $15.5 \mathrm{~mm}$. The parameters of the turbulent specification are implemented in the TFC model. The two sections are done within the combustor is depicts in Table 1. The two sections represent each part of the combustor which contains in the sections that is used in the simulation and explained in the results and in Figure 3.

The changes in intake $\&$ exhaust valves, timing periods are explained in Figure 2. Exhaust valve opening $\&$ closing times were fixed. The exhaust valve was opened in point (3) and closed in point (1). The intake valve was opened in point (4) and closed in point (2). The high compression ratio allowed alteration in valve activity during the overlap duration into TDC point to avert valve to contact the piston [4].The summary of valve timing within crankshaft angle CA is restricted in Table 2. Moreover, the initial and boundary conditions used within the TFC model, meanwhile the fuel types and specifications are listed in Table 3.

In this study, we use 3-D simulation of turbulent combustion modeling in SI engine. This modeling becomes an essential tool in the analysis and design of the high efficiencies and low emissions from the engines. The grid is unstructured polyhedral mesh with total number of cells and faces of each part as the follow: Body 1 : 26242 cells, 150951 faces, Body 2 : 942 cells, 4060 faces, Body 3 : 932 cells, 4071 faces and Body 4 : 768 cells, 3311 faces depicted in Figure 3. The simulations are carried out by the STAR CCM+ (v10.02) CFD software [30]. The realizable $\mathrm{k}-\varepsilon$ two layer model is used for turbulence modeling. The boundary conditions are included: velocity inlet condition in the injector of the fuel, pressure outlet in the valves when was opened and the wall when was closed.

The turbulent flame speed $\left(\mathrm{S}_{\mathrm{T}}\right)$ utilized in the simulation can be calculated from the formulation of TFC reaction with the CFD software as below [30].

$\mathrm{S}_{\mathrm{T}}=\operatorname{AG}\left(\mathrm{S}_{\mathrm{L}}^{0.5} \alpha_{\mathrm{u}}^{-0.25} \dot{\mathrm{u}}^{0.75} \mathrm{l}_{\mathrm{t}}^{0.25}\right)$
Where, $\mathrm{A}$ is a TFC model constant, $\mathrm{G}$ is the flame stretch factor, $\alpha_{\mathrm{u}}$ is the thermal diffusivity of the mixture, $S_{L}$ is the laminar flame speed, and $l_{t}$ turbulent length scale. Then the turbulent kinetic energy $\mathrm{k}$ which is represented the turbulence level within the combustor can be found from this equation [31].

$\mathrm{k}=1.5\left(\mathrm{u}^{\prime}\right)^{2}$

where, $u^{\prime}$, is the root mean square of the velocity.

The heat release from burning gasoline can be determined from energy equation as [30].

$\mathrm{HR}=\sum_{\mathrm{i}=1}^{\mathrm{n}} \mathrm{h}_{\mathrm{i}} \rho_{\mathrm{u}} \mathrm{S}_{\mathrm{T}}\left|\nabla \mathrm{Y}_{\mathrm{f}}\right|$

where, $h_{i}$ is the heating value of gasoline, $\rho_{u}$ is the unburnt density and $\mathrm{Y}_{\mathrm{f}}$ is fuel mass fraction as listed in Table 3.

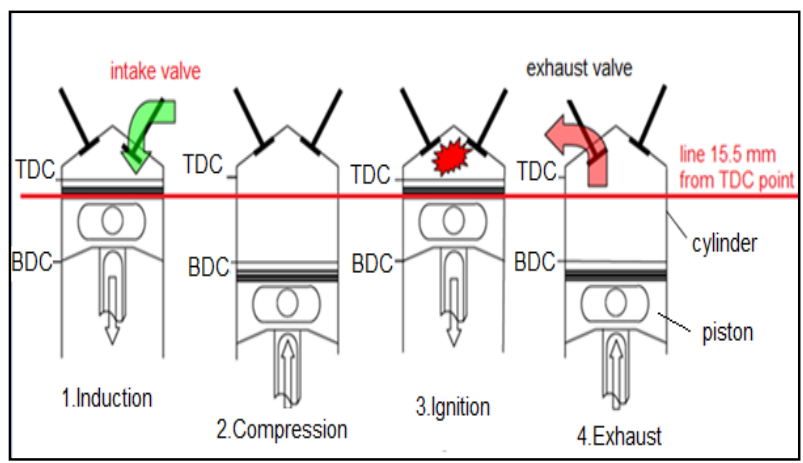

Figure 1: 4- stroke engine stages with valves and the $15.5 \mathrm{~mm}$ line location

Table 1 Sections of the combustor and its parts.

\begin{tabular}{|l|c|l|l|c|}
\hline Section & Fuel injector & Intake valve & Exhaust valve & Cylinder \\
\hline 1 & $\checkmark$ & & & $\checkmark$ \\
\hline 2 & & $\checkmark$ & $\checkmark$ & $\checkmark$ \\
\hline
\end{tabular}

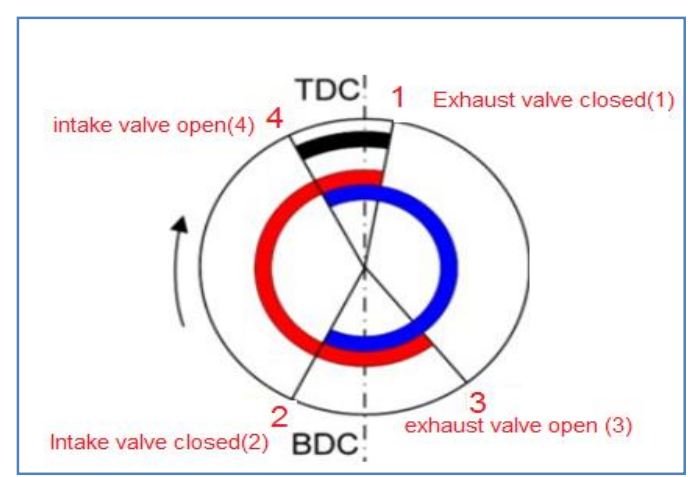

Figure 2: Valve timing diagram [29] 


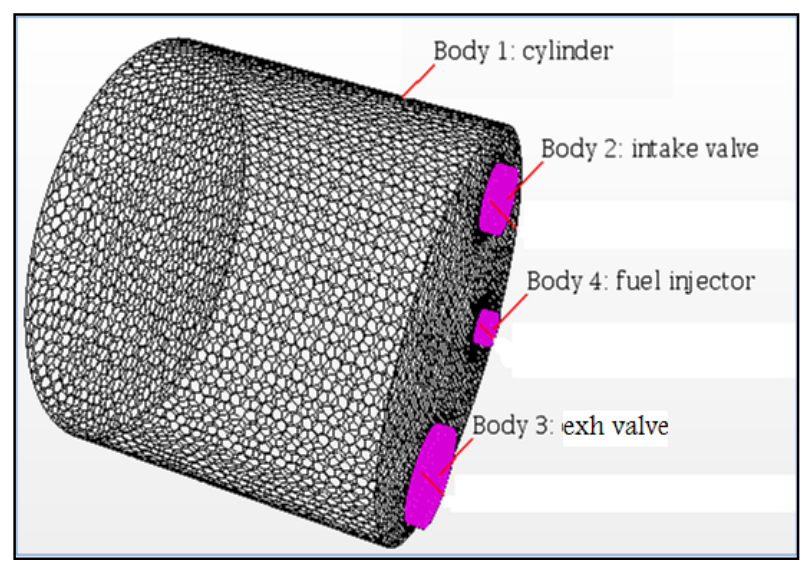

Figure 3: the mesh of the cylinder and valves

Table 2 valves timing specification.

\begin{tabular}{|l|l|l|}
\hline valve & Open & Closed \\
\hline Intake & $19^{\circ} \mathrm{CA}$ & $38^{\circ} \mathrm{CA}$ \\
\hline Exhaust & $59^{\circ} \mathrm{CA}$ & $8^{\circ} \mathrm{CA}$ \\
\hline
\end{tabular}

Table 3 Initial and boundary conditions and type of fuel and its specification used in the TFC model.

\begin{tabular}{|c|c|c|c|c|}
\hline $\begin{array}{c}\text { Equivalence } \\
\text { ratio }\end{array}$ & $\begin{array}{c}\text { Initial } \\
\text { temperature[K] }]\end{array}$ & $\begin{array}{c}\text { Fuel mass } \\
\text { fraction }\end{array}$ & $\begin{array}{c}\text { 0xygen mass } \\
\text { fraction }\end{array}$ & $\begin{array}{c}\text { Nitrogen mass } \\
\text { fraction }\end{array}$ \\
\hline 0.6 & 300 & 0.038 & 0.235 & 0.726 \\
\hline Fuel type & $\begin{array}{c}\text { heating value of } \\
\text { the fuel } \\
{[\mathrm{kJ} / \mathrm{g}]}\end{array}$ & $\begin{array}{c}\mathrm{TFC} \text { model } \\
\text { constant( }(\mathrm{A})\end{array}$ & $\begin{array}{c}\text { Turbulent } \\
\text { kinetic energy } \mathrm{k} \\
{[\mathrm{J} / \mathrm{kg}]}\end{array}$ & $\begin{array}{c}\text { Turbulent } \\
\text { dissipation rate } \\
{[\mathrm{m} 2 / \mathrm{s} 3]}\end{array}$ \\
\hline $\begin{array}{c}\text { Gasoline } \\
\text { C8H18 }\end{array}$ & 47.8 & 0.37 & 0.0324 & 0.04 \\
\hline
\end{tabular}

\section{Results and Discussion}

The turbulent flame speed $\left(\mathrm{S}_{\mathrm{T}}\right)$ utilized in the TFC model for a better description of the ignition flame evolution. The distribution of $\mathrm{S}_{\mathrm{T}}$ in the line $15.5 \mathrm{~mm}$ below TDC point in the radial direction of the cylinder within valves timing i.e. when the exhaust valve is closed and both valves (intake / exhaust) are closed is depicts in Figure 4. It's clear that $\mathrm{S}_{\mathrm{T}}$ is high values at the middle region and low quantity at regions near the wall within the cylinder due to the stagnation of the flow. The lower $\mathrm{S}_{\mathrm{T}}$ occurs when the exhaust valve is closed case only.

Figure 5 shows the heat release from the combustion at two cases of the valve timing. The heat released when the exhaust valve is closed at the $8^{\circ} \mathrm{CA}$ is lower heat released than both valves are closed case in the radialdirection within the cylinder at $15.5 \mathrm{~mm}$ line below TDC point. While Figure 6 shows distribution of the temperature in the $15.5 \mathrm{~mm}$ line below the TDC point within valves timing. The minimum temperature occurs when the exhaust valve is closed only case and maximum temperature reached $1600 \mathrm{~K}$. In addition, the heat transfer is enhancement by $2.94 \%$.

The turbulent kinetic energy $(k)$ is very important parameter in turbulent flame in SI engine. Figure 7 shows the $\mathrm{k}$ contour in sections 1 and 2 within the cylinder at the exhaust valve closed. While the inverse case happened when close the intake valve and the exhaust valve is open as depicted in Figure 8. The $S_{\mathrm{T}}$ used in the model for high description of the ignition flame development. The contours of the, $S_{\mathrm{T}}$ are depicted in Figures 9 and 10 with different cases of valve timing which are listed in Table 2. The exhaust valve case has important effect on $\mathrm{S}_{\mathrm{T}}$ parameter on the flame spread.

The influences of fuel temperature $[\mathrm{K}]$ and engine speed [rev/min] on the engine performance and brake mean specific fuel consumption (BSFC) with 2500 [rev/min] are depicted in Figures 11 and 12 respectively. Higher values of fuel temperature are produce utmost conditions for both engine performance and exhaust emission. Hence, the brake power (rate of work of the engine) enhances by $3.22 \%$ for $2500 \mathrm{rpm}$ with increase fuel temperature $60 \mathrm{~K}$. Meanwhile, enhances $43 \%$ from change $2500 \mathrm{rpm}$ to $5500 \mathrm{rpm}$. The minimal BSFC (252.1 g/kW-hr) was acquired at minimal temperature of $330 \mathrm{~K}$, while the maximum BSFC (353.6 $\mathrm{g} / \mathrm{kW}$-hr $)$ was acquired at temperature of $343 \mathrm{~K}$. The higher brake mean specific fuel consumption is due to the lower energy content of the fuel. As the temperature increases, the energy content also increases, causing the lowest BSFC for a temperature of $330 \quad \mathrm{~K}$. 


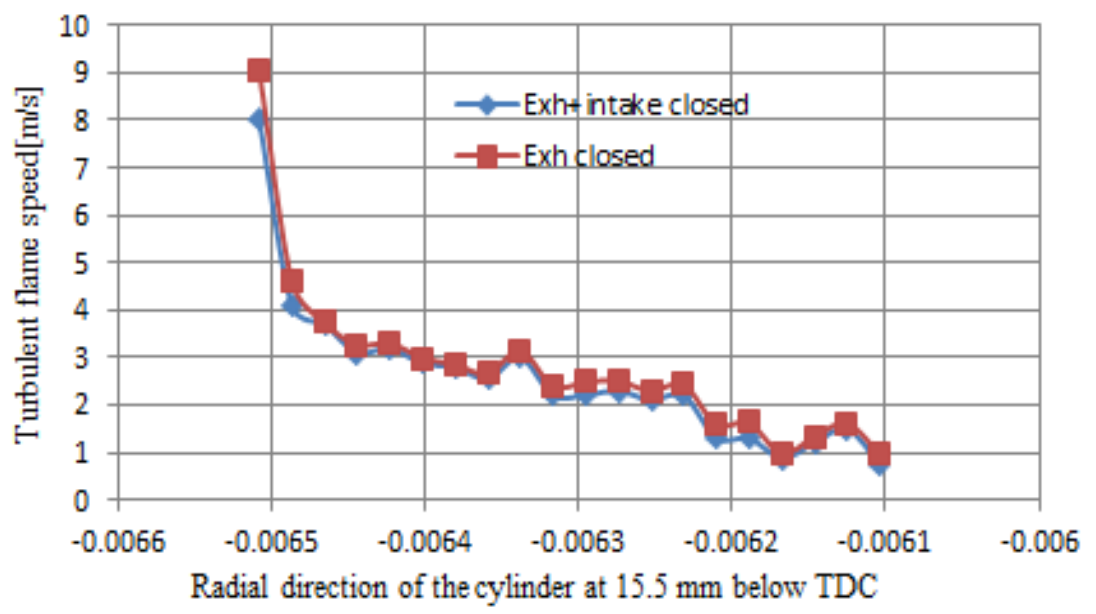

Figure 4: turbulent flame speed $\mathrm{S}_{\mathrm{T}}$ distribution at the line $15.5 \mathrm{~mm}$ below TDC

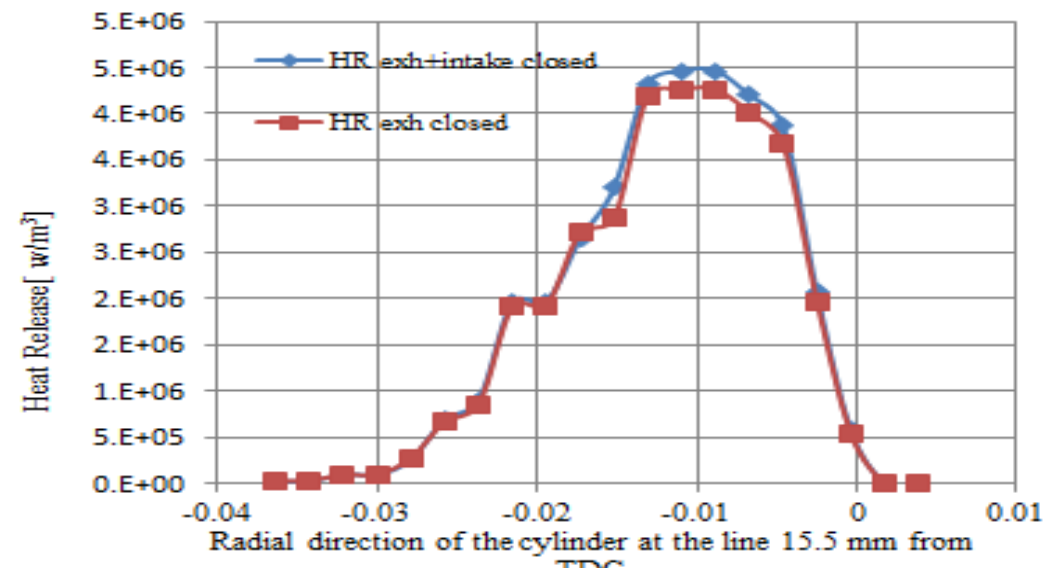

Figure 5: heat release at the line $15.5 \mathrm{~mm}$ below TDC point

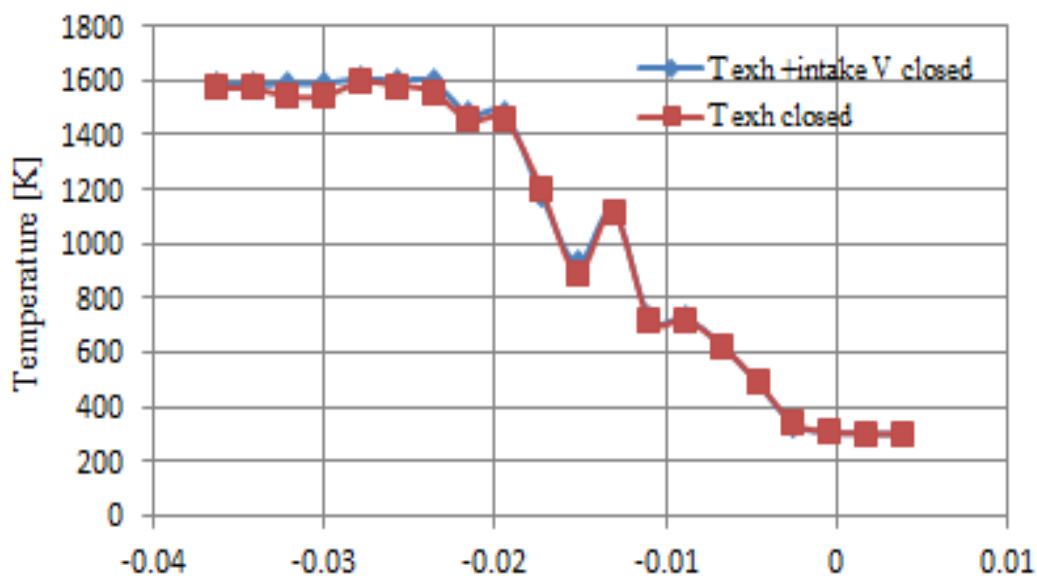

Radial direction of the cylinder at the line $15.5 \mathrm{~mm}$ from TDC

Figure 6: temperature distribution at the line $15.5 \mathrm{~mm}$ below TDC point 


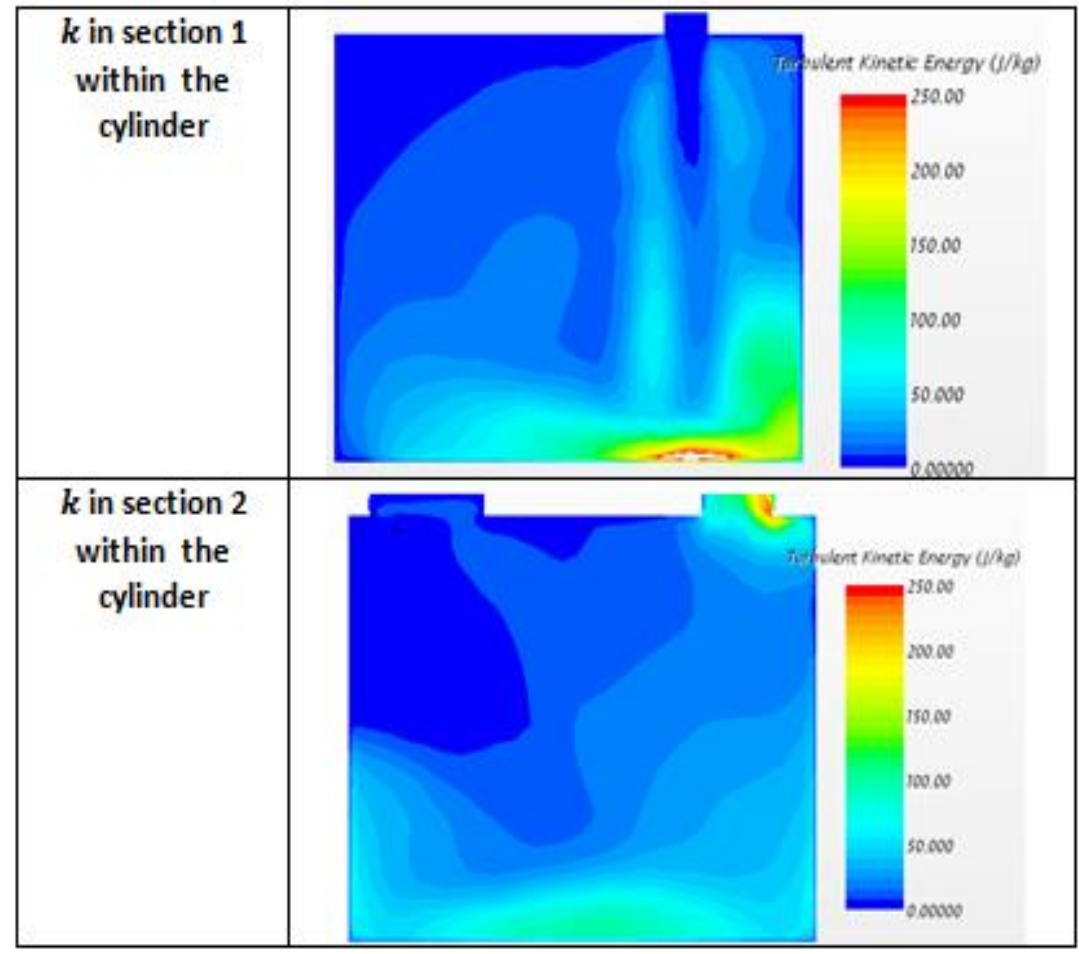

Figure 7: Turbulent kinetic energy $(k)$ contour in sections 1 and 2 in the cylinder at exhaust valve closed

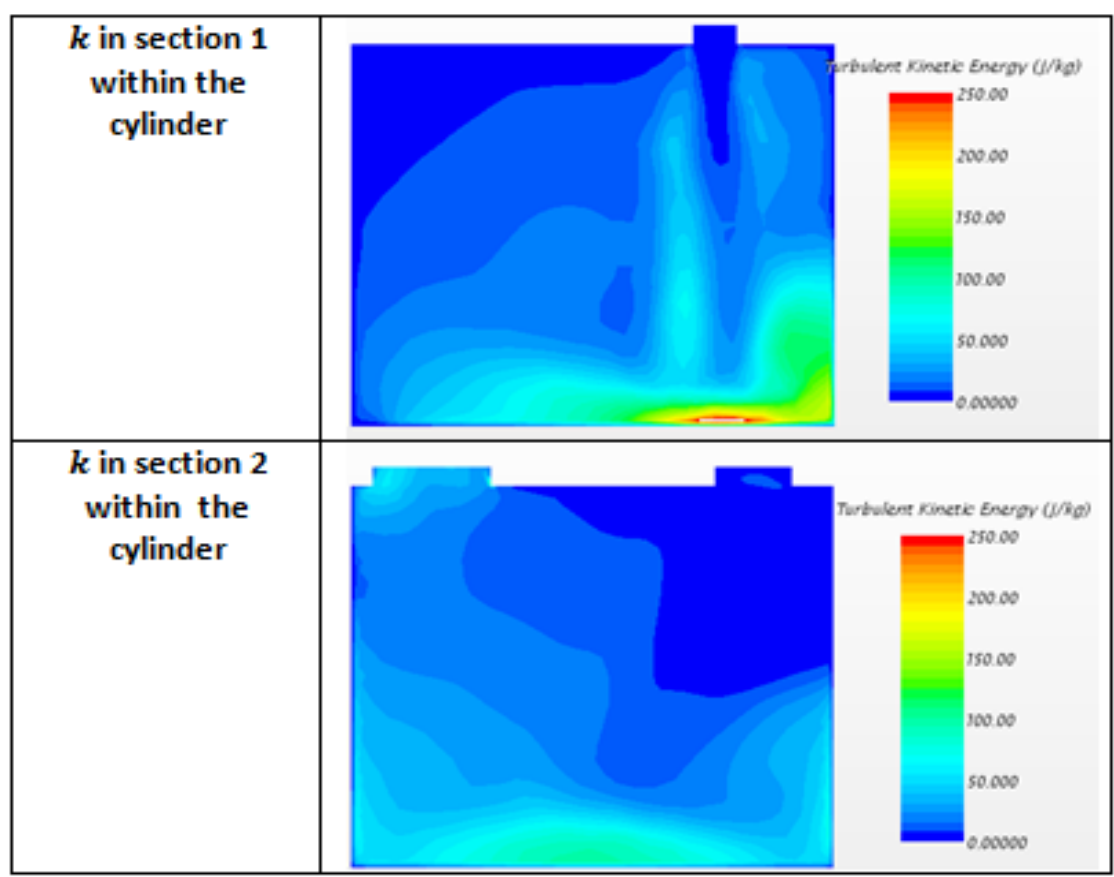

Figure 8: Turbulent kinetic energy $k$ contour in sections 1 and 2 in the cylinder at exhaust valve open 


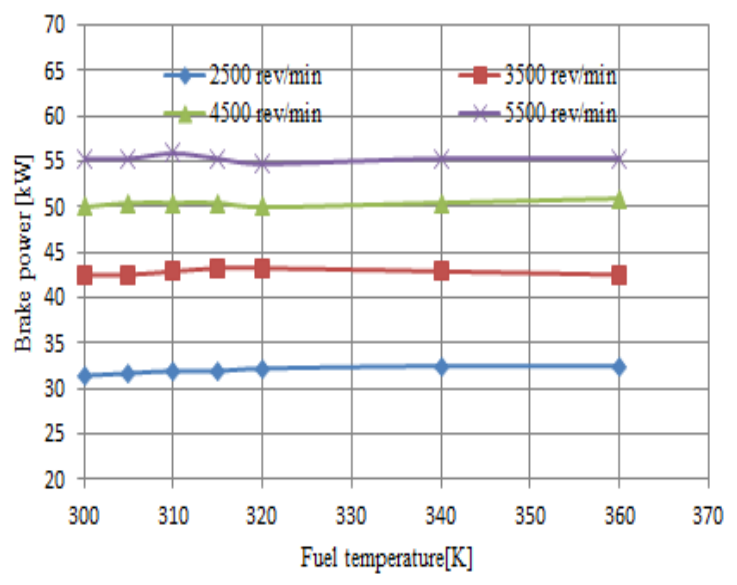

Figure 11: brake power of the engine at different fuel temperature and engine speed

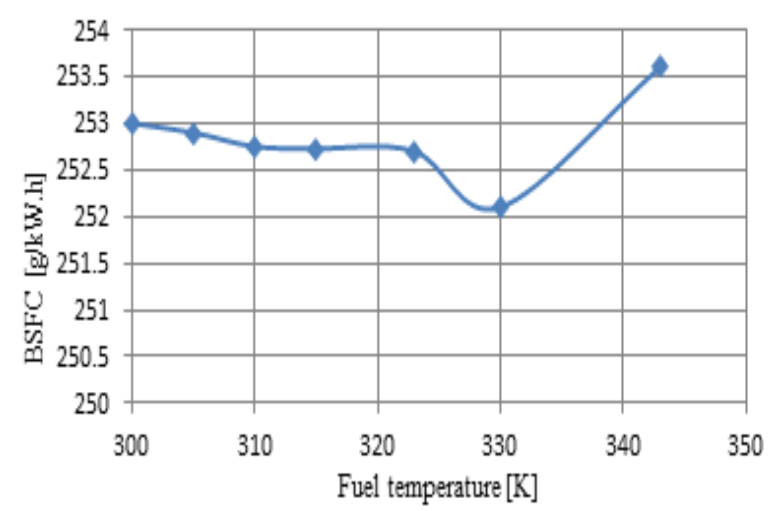

Figure 12: the brake mean specific fuel consumption in different fuel temperature at engine speed 2500 [rev/min]

\section{Conclusions}

The turbulent combustion simulation is performed in four stroke SI engine. The simulation performed by using STAR CCM+ v 10.02 software. TFC model used in different turbulent flow conditions. The turbulent flame speed, $\mathrm{S}_{\mathrm{T}}$ turbulent kinetic energy $k$ and the heat released from the combustion in the radial direction of the cylinder at $15.5 \mathrm{~mm}$ below the TDC point are studied with the influence of the valves timing. The simulation performs within cases of the (intake / exhaust) valve timing. We found that the exhaust valve case is a very important leverage on the turbulent flame specification. The turbulent flame speed is growing by $8.31 \%$ in case of intake and exhaust valves are closed. The heat transfer is enhancing by $2.94 \%$ when intake and exhaust valves are closed. The results show that at higher values of fuel temperature produces maximum stipulation for both engine performance and exhaust emission.

\section{References}

[1]. S. Grasreiner, Combustion Modeling For Virtual -SI Engine Calibration with the Help of 3D Methods, p. 179, 2012.

[2]. L. Liang \& R. Reitz, SI Engine Combustion Modeling Using a Level Set Method with Detailed, SAE Pap. 2006-01-0243, vol. 2006, no. 724 , (2006).

[3]. V. Zimont, F. Biagioli, \& K. Syed, Modelling turbulent - premixed combustion in the intermediate steady propagation regimes, Prog, Comput. Fluid Dyn. an Int. J., 1(1), (2001), 14-28.

[4]. J. Duclos, M. Zolver, \& T. Baritaud, 3D modelling of combustion for DI/SI engines, Oil Gas Sci. Technol., 54, (2), (1991), 259-264.

[5]. C. V. Rajam, P. V. K. Murthy, M. V. S. M. Krishna, G. M. Prasada, and N. Dist, Design Analysis and Optimization of Piston using CATIA and ANSYS, Vathsalya Inst. Sci. Technol., 1, ( 2), (2013), 41-51.

[6]. I. Ahmed, Simulation of turbulent flames relevant to spark-ignition engines, Ph.D thesis. University of Cambridge, 2014.

[7]. H. Wu, Study of SI Engine Combustion Model for the Analysis of Cyclic Variation \& Combustion Stability At Lean, 2013.

[8]. T. Mastorakos, Turbulent Combustion Modeling, Fluid Mech. its Appl., 95, (2011), 119-142.

[9]. S. Haider, Combustion \& radiation modelling of laminar premixed flames using Open Foam: numerical investigation of radiative heat 
transfer in RADIADE project, 27th

CIMAC World Congr., 2013.

[10]. A.. Aziz, A. Abd Rahman, \& A. A. Hassan, Design of customized modular cylinder head for SIengine, ARPN J. Eng. Appl. Sci., 10, (17), (2015), 7729-7733.

[11]. D. Linse, B. Durst, C. Hasse, S. Toninel, T. Frank, H. Forkel, \& A. Germany, Simulating Combustion in Spark Ignition Engines with ANSYS CFX, no. July, (2009), . 113.

[12]. J. Howell, R. Siegel, and M. Mengüc, Thermal Radiation Heat Transfer, Taylor and Francis 5( 9), (2013).

[13]. Bureau of Energy Efficiency, Fuels and Combustion, Energy Effic. Therm. Util., pp. 1-28.

[14]. J. H. Lienhard, Heat Transfer, J. Heat Transfer, 82, (1), (20100, 198.

[15]. F. Dinkelacker \& S. Hölzler, Investigation of a TFC Approach for Premixed- Flame Calculations, Science (80-.). 158, no. September, (2000), pp. 321-340.

[16]. Ö. L. G. a \& G. J. SMALLWOOD, Flame Surface Densities in Premixed Combustion At Medium To High Turbulence Intensities, Combust. Sci. Technol., 179 (1-2), (2007), 191-206.

[17]. P. Tamadonfar \& Ö.. Gülder, Experimental investigation of inner structure of premixed turbulent methane-air flames in the thin reaction zone regime, Combust. Flame, 162, (1), (2015), 115-128.

[18]. A. N. Lipatnikov \&J. Chomiak, Premixed Turbulent Flame Theory $\&$ Simulations of Combustion in- SI Engines: Connectionsi Discrepancies, and Practical Solutions, Intern. Rep. Chalmers Univ., 1, (2015), 1689-1699.
[19]. V.Zimont, An efficinent computional model for premixedturbulent combustion at high Reynolds number based on a TFC, 1997.

[20]. L. Qiao, Y. Gan, T. Nishiie, W. J. a Dahm, \& E. S. Oran, Extinction of premixed methane-air flames in microgravity by diluents: Effects of radiation \& Lewis number, Combust. Flame, 157, ( 8), (2010), 1446-1455.

[21]. B. O. Ayoola, R. Balachandran, J. H. Frank, E. Mastorakos, \& C.. Kaminski, Spatially resolved heat release rate measurement in turbulent premixed- flames, Combust. Flame, 144, (1-2), (2006), $1-16$.

[22]. V. Zimont \& F. Biagioli, Modelling turbulent premixed- combustion in the intermediate steady propagation regimes, Prog, Comput. Fluid Dyn. an Int. J., 1, ( 1), (2001), 14-28.

[23]. T. Echekki \& E. Mastorakos, Turbulent Combustion ModelingSpringer Dordrecht Heidelberg London, 2011.

[24]. B. Park \& K. Kundu, a Simplified Reaction Mechanism for Propane Combustion, 960-967.

[25]. Z. Yan, Numerical Modelling of Turbulent Combustion and Flame Spread, Lund, 1999.

[26]. H. A. Ibrahim, Fired process heaters, MATLAB Appl. Pract. Eng., (2014), 327-365.

[27]. A. Fallis, Turbulent Flame Speed in -SI Engine Combustion Process Using CFD, J. Chem. Inf. Model., 53, (9), (2013), 1689-1699.

[28]. J. Heywood, Internal CombustionEngine Fundementals, vol. 21. 1988.

[29]. C. ÇINAR \& Fazıl AKGÜN, Effect of Intake Valve Closing Time on 
Engine Performance \& Exhaust

Emissions in - Spark Ignition

Engine, (2007), 371-375.

[30]. CD-adapcoTM, STAR-CCM +v 11_ user guide, 2016.

[31]. S. B. Pope, Turbulent Flows, Cambridge Univ. Press, 1, (2000), 771.

[32]. Singh, N. J., and Pandey, R. K., Neural Network Approaches for Prediction of Drying Kinetics During Drying of Sweet Potato, J. Agricultural Engineering International: CIGR, 13, (1), (2011). 